Please do not remove this page

RMIT

UNIVERSITY

\title{
Defining and Inscribing 'Multicultural Library Services' in Australia: A Case Study of the Working Group on Multicultural Library Services (Victoria)
}

Hegarty, Kieran

https://researchrepository.rmit.edu.au/esploro/outputs/9921970608301341/filesAndLinks?institution=61RMIT_INST\&index=null

Hegarty, K. (2021). Defining and Inscribing "Multicultural Library Services" in Australia: A Case Study of the Working Group on Multicultural Library Services (Victoria). Journal of the Australian Library and Information Association, 70(1), 44-59. https://doi.org/10.1080/24750158.2021.1875972

Document Version: Accepted Manuscript

Published Version: https://doi.org/10.1080/24750158.2021.1875972

Repository homepage: https://researchrepository.rmit.edu.au

(c) 2021 Kieran Hegarty

Downloaded On 2023/04/26 10:53:02 +1000 


\section{Journal of the Australian Library and Information Association \\ Defining and inscribing 'multicultural library services' in Australia: a case study of the Working Group on Multicultural Library Services (Victoria) \\ --Manuscript Draft--}

Full Title:

Defining and inscribing 'multicultural library services' in Australia: a case study of the Working Group on Multicultural Library Services (Victoria)

Manuscript Number:

Article Type:

Keywords:

Abstract:
UALJ-2020-0039R2

\section{Research}

multiculturalism, migrants, professional groups, libraries, diversity, social justice

In this article, I survey efforts by librarians to alter collections and services amidst the demographic and political transformations of late twentieth century Australia. To examine this complex history, I focus on the Working Group on Multicultural Library Services (Victoria). For two decades, this independent group were active in positioning public libraries as key to the promotion and endorsement of a multicultural Australia. Using Group archives and interviews with key members, I argue that dominant understandings of recognising and accommodating cultural difference in libraries reflect the limitations of state multiculturalism. To demonstrate this, I focus on two Group activities: the state-wide adoption of the Standards for multicultural public library service, and lobbying by the Group for a national languages policy. While the former adopted the language of welfare provision based on discrete ethno-cultural groups, the latter echoed the emerging policy discourse of 'productive diversity'. In this case study, I critique the politics embedded in how 'cultural diversity' is typically understood within libraries and how library policies and practices are implicated in broader social and political developments. Such an approach offers insight into steady shifts in how the role of public libraries in culturally heterogenous societies have been debated and defined. 


\title{
Defining and inscribing 'multicultural library services' in Australia: a case study of the Working Group on Multicultural Library Services (Victoria)
}

\author{
Submission type: Double blind peer reviewed research paper
}

Word count: 6351

Special issue: Libraries and the Community: Representing and reflecting cultural diversity in library research, policy and practice (edited by Ian McShane and Jodie Boyd)

\section{Kieran Hegarty*a}

${ }^{a}$ PhD student, Centre for Urban Research, RMIT University, Melbourne, Australia

*Corresponding author: Kieran Hegarty (s3829364@student.rmit.edu.au), Centre for Urban Research, Level 11, Building 8, RMIT University, Melbourne, Australia.

Kieran Hegarty (AALIA CP) is a PhD candidate at the Centre for Urban Research at RMIT University, where he is researching the sociotechnical imaginaries in national web archiving projects. His doctoral research will contribute to the ARC Linkage project 'Representing Multicultural Australia in National and State Libraries' (2018-2021), run in partnership with National and State Libraries across Australia. Trained in both sociology and library and information studies, Kieran also provides research support to the Monash Migration and Inclusion Centre at Monash University, where he has contributed to major projects evaluating how public institutions and neighbourhoods have responded to increasing social and cultural diversity. His recent publications focus on how economic, demographic, and political upheaval impacts social dynamics and intercultural relations in different communities.

Acknowledgements: Research for this paper was supported by Australian Research Council grant LP170100222. I thank my supervisors Ian McShane and Jodie Boyd for their encouragement, former members of the Working Group on Multicultural Library Services (Victoria) who I interviewed for generously sharing their experiences, and State Library Victoria staff for their assistance with access to archival materials. 


\title{
Defining and inscribing 'multicultural library services' in Australia: a case study of the Working Group on Multicultural Library Services (Victoria)
}

\author{
In this article, I survey efforts by librarians to alter collections and services \\ amidst the demographic and political transformations of late twentieth century \\ Australia. To examine this complex history, I focus on the activities of the \\ Working Group on Multicultural Library Services (Victoria). This independent \\ group of librarians were active in defining and inscribing 'multicultural library \\ services' across the Australian library sector in the two decades following their \\ formation in 1979. Drawing on primary sources from the Group and interviews \\ with key members, I argue that dominant understandings of recognising and \\ accommodating cultural difference remain rooted in the social and political \\ context in which the group was established. I focus on two key Group activities \\ that sought to position public libraries as key to the promotion and endorsement \\ of a multicultural Australia: the state-wide adoption of the Group's Standards for \\ multicultural public library service, and lobbying by the Group for a national \\ languages policy and federal government funding for public libraries. While the \\ former adopted the language of ethno-specific welfare provision based on \\ discrete cultural groups, the latter echoed the emerging policy discourse of \\ 'productive diversity'. In this brief history, I offer insight into the assumptions, \\ ethics, and politics embedded in how 'cultural diversity' is typically understood \\ within libraries and the ways in which library policies and practices are \\ implicated in broader social and political developments. Such an approach offers \\ insight into steady shifts in how the form and function of public libraries in \\ culturally diverse societies such as Australia have been debated and defined.
}

Keywords: multiculturalism, migrants, professional groups, libraries, diversity, social justice

\section{Introduction: The durability of 'diversity' in the Australian library sector}

Early in 2020, INCITE, the trade magazine distributed to librarians across

Australia, published a special issue on the theme of 'critical librarianship'. In its pages, members of the Australian Library and Information Association (ALIA) spoke of efforts 
to advance principles of 'social justice', 'diversity' and 'inclusion' in their organisations (McCulloch, 2020, p. 24). Such evocations have a much longer history. Four decades prior, delegates met for the first National Conference on Multiculturalism and Libraries in Melbourne (Holmes et al., 1981). The conference was a landmark event for its focus on how libraries should define their roles and responsibilities in a country redefining itself in terms of 'multiculturalism': a contested and shifting set of ideologies, policies, and programs designed to recognise and manage Australia's cultural and linguistic diversity and at various moments conceptualise contemporary citizenship. I use the 1980 conference to commence my reflection on how library staff have responded to demographic and political transformations over the past four decades and the dominant ways that 'difference' has been recognised and accommodated. The group responsible for the conference was the Working Group on Multicultural Library Services (Victoria), which formed in 1979 under the leadership of Radha Rasmussen from the Monash School of Librarianship. Joined by librarians working across Victoria, many of them in public libraries, this independent group advanced its mission of providing 'fair and equitable library service to all Victorians, whatever their culture or language' (Working Group on Multicultural Library Services (Victoria), 1980). Over the following two decades, the Group led a coordinated response from the Victorian library sector to official multicultural policies and programs that proved influential nationally and internationally. In part through their work, a particular model of 'multicultural library services' was defined and inscribed in the Australian public libraries.

I use the activities of the Working Group on Multicultural Library Services (Victoria) to explore the assumptions, ethics, and politics embedded in how libraries and library staff have understood and responded to demographic, political, and cultural transformations in Australia over the past forty years. The aims of this article are two- 
fold. First, reviewing this history offers an insight into why the question of who is and is not served and represented by Australian libraries remains highly relevant and contentious. To examine this, I draw on critiques of state multiculturalism to suggest that the limitations embedded in the liberal politics of recognition extend themselves to the library sector.

Second, I hope to demonstrate the ways in which library policies and practices are implicated in broader social and political developments. By exploring the ways in which collecting practices, modes of description and access, and services have (and have not) shifted in response to social and political change, I outline the dominant ways in which 'cultural difference' is constructed and accommodated. My aim is not a definitive history of multiculturalism and libraries, but rather a reflection on whether practices aimed to recognise and celebrate 'diversity' in the library sector sustain or disrupt dominant narratives around collective identity, culture, and heritage. Through my analysis of the Group, I offer a historical context to many of the themes discussed in this special issue, and an insight into what makes the concerns addressed in the January 2020 issue of INCITE so durable, yet still unresolved.

\section{Literature review: towards a critical approach to 'multicultural library services'}

\section{'Multiculturalism' in LIS scholarship: from valorisation to critique}

Contemporary library and information science (LIS) scholarship, particularly from the area broadly defined as 'critical librarianship', is increasingly challenging notions that library systems, practices, and spaces are - or ever have been - politically neutral. Originating in the United States, the 'critlib' movement has drawn attention to how commercial library systems, standardised practices, and a lack of workplace diversity in the sector reflect and reinforce power hierarchies in broader society. The 
movement aims to mobilise librarians to challenge the submergence of libraries in capitalist, colonial, and patriarchal systems of knowledge production. Publishers Litwin and Library Juice Press produce a steady stream of 'critlib' literature, with several edited volumes, works in translation, and a journal to advance the field. Librarians, aided by social media, are certainly discussing and debating such concerns ${ }^{1}$. Whether systematic change is afoot is far more contested, as evidenced in ALIA's recent report on the relative homogeneity of the Australian library workforce (ALIA, 2019).

In Australian libraries, a recent trend at an institutional level is to adopt 'diversity' and 'inclusion' policies and plans in an apparent attempt to better recognise and reflect Australia's social pluralism in collections, programs, and workforces. Such initiatives, including 'cultural competence' training in LIS education and the workplace, have formed the focus of two recent journal articles in Australian LIS scholarship (Blackburn, 2015; Maestro et al., 2018). Critical race scholars, as well as critical librarians, have suggested that institutional commitments to 'diversity' perform a largely symbolic function that do little to disrupt institutional racism and white dominance. For example, Christine Pawley (2006) has suggested the proliferation of 'inclusive' terms such as 'multiculturalism' and 'diversity' in mainstream LIS curricula fail to address the complex and overlapping dimensions of 'race', gender, class, ethnicity, and sexuality that underpin the reproduction of inequalities in the library sector. More recently, David James Hudson (2017, p. 6) frames 'diversity’ policies and programs in the sector as benign forms of 'liberal anti-racism' that ignore the structural

1 "Critlib is short for "critical librarianship," a movement of library workers dedicated to bringing social justice principles into our work in libraries' that is sustained through regular discussion on Twitter using the hashtag \#critlib (http://critlib.org/about/). 
and historical nature of economic and cultural domination that see the continued primacy of particular bodies and narratives in positions of power. In these critiques, 'diversity' and 'inclusion' policies - as well as initiatives such as 'cultural competence' training - are seen largely as tokenistic gestures that fail to meaningfully recognise and respond to ongoing inequalities.

Little has been written on efforts made in the Australian library sector to respond to this country's evolving history, and the traces of power that see the continued primacy of white bodies and narratives in the cultural sector. A recent report by Diversity Arts Australia (2019) found that culturally and linguistic diverse Australians were under-represented across every leadership role in every cultural sector, organisational type, and jurisdiction surveyed. Meanwhile, ALIA's 2019 Workforce Diversity Trend Report has suggested that the library workforce is more culturally homogeneous that the wider labour force and Kirstin Thorpe (2019) has noted a tendency in the library sector to address 'complex problems with practical and temporary solutions' rather than seeking longer-lasting, structural changes. Despite 'diversity' being valorised at an institutional level, library collections, systems, and workforces continue to reflect inequalities that exist more broadly in Australian society.

\section{Critical studies of state multiculturalism in Australia}

In the social sciences, there has been considerable scholarly effort spent on understanding why, despite decades of recognising - and in many cases, celebrating Australia's cultural diversity, particular forms of cultural expression continue to predominate. Several scholars have diagnosed this paradox as being caused by the modes in which the state has historically categorised and sought to govern cultural difference. One of Australia's leading sociologists on multiculturalism, Andrew Jakubowicz (1981), argues that multicultural policy emerged as a way to neutralise the 
structural and material concerns of non-English-speaking migrant groups through accommodation in various state programs. In the late 1970s, these programs were competitively administered through ethnic community organisations, and ethnicity emerged as state multiculturalism's main 'building block' (Ang, 2001, p. 199). Sociologists examining the implications of such policies understand state multiculturalism as the mode by which the dominant political culture was able to reproduce itself (Castles, 1992; Jakubowicz, 1981, 1994). In these arguments, multiculturalism is adopted by the dominant classes to neutralise rival political claims by advancing minority inclusion into a dominant national culture largely defined by white elites.

Building on this work, social and cultural theory emerged from the 1990s that theorised on the power relations embedded in the politics of multiculturalism and how dominant histories, identities, and narratives reproduce themselves in Australia. Ien Ang (2001), Ghassan Hage (1998), Jon Stratton (1998), and Sneja Gunew (2004) all published influential books on how power operates implicitly in multicultural politics and society. Taken together, this body of work identifies three interconnected limitations with state multiculturalism as a framework for advancing equality. First, by framing cultural difference according to ethnicity, it ignores the powerful role race plays in stratifying social relations. Second, it masks the continued hegemony of 'AngloCeltic' culture; under state multiculturalism, white Australia remains the norm to which all others deviate. Lastly, it is bounded on the premise of stable and separate cultures, ignoring the cultural complexity of contemporary Australia society and the hybridity of contemporary cultures and identities. In these critiques, both proponents and opponents of multiculturalism perpetuate power imbalances that fall along lines of ethnicity and 'race'. 
These arguments have been advanced theoretically by feminist scholar Sara Ahmed (2000, p. 99) who asserts that the act of "welcoming "the stranger" produces the very figure of “the stranger" who can be taken in'. In Ahmed's (2000, p. 108) critique, the liberal multicultural nation can only accept 'those differences that do not the threaten the "we" of an Australian being'. Similarly, anthropologist Elizabeth Povinelli (2002, p. 68) argues that liberal forms of recognition demand the performance of an impossibly 'authentic' self-identity - one that is 'maximally other than dominant society and minimally abrasive to dominant values' - in order to secure the distribution of resources. While Povinelli focusses on how liberal multiculturalism operates specifically in relation to First Nations people, her work remains a useful way to consider the boundaries of 'acceptable' modes of cultural expression within a liberal state more generally, and why the politics of recognition often do little to disrupt hegemonic ways of being. Both Ahmed and Povinelli argue that by demanding 'acceptable' forms of cultural beliefs and practices from minority and subaltern subjects, liberalism defuses struggles for liberation against it. 'Recognition' is thus dependent on stable, static, and deeply apolitical articulations of culture that serve 'national hegemonic projects rather than subaltern standards or dreamings' (Povinelli, 1998, p. 610). In this work, it is in the techniques of liberalism that recognition is both advanced and limited to produce specific 'multicultural subjects' and controlled forms of cultural expression.

Starting in the late 1980s, Australia's immigration program and cultural diversity has been increasingly mobilised to serve political and economic ends. Ien Ang (2001) asserts that, in the early 1990s, Australia's cultural pluralism became a symbol that the state sought to use for its economic advantage in the context of a rapidly globalising economy. Ang (2001, p. 153) suggests migration and cultural policy under 
Labor Prime Minister Paul Keating (1991-1996) sought to position Australia as an 'outward-looking, cosmopolitan and worldly nation, fully integrated and thriving in the global village and the new world order'. During this period, Australia's demography and geography was no longer something to be contained; rather, 'diversity' could be economically and socially 'productive'.

Despite (or perhaps because of) the shifting politics of diversity, dominant forms of cultural expression continued to occupy a privileged position. Scholars have linked this paradox - marginalisation despite celebration - to the inherently conservative way culture is treated in multiculturalism. For example, Gunew (1990) argues that the 'culture' recognised in multiculturalism is seen as static and separate, ignoring how cultures are in a constant process of adaptation and evolution. In these critiques, 'cultural diversity' is mobilised to serve purely economic and political ends, neutralising rival expressions of national culture. This body of work offers a framework for examining how multicultural politics constructs, mobilises, and limits particular modes of knowledge production in which cultural institutions like public libraries are implicated.

\section{Towards a critical outline of 'multicultural library services' in Australia}

Critical studies of state multiculturalism reviewed above suggest that dominant modes of conceptualising difference produce a certain subject position; one framed in terms of deficits or divergences from the norm and limited in its political potential. Cultural difference and diversity, whether minimised, mobilised, or simply accepted, is neutralised by the power structures underpin that liberal forms of recognition. This is framed by the power traces embedded in the continued centrality of whiteness within Australian history, politics, and society. So, how have libraries responded to Australia's social and cultural transformations over the past fifty years? In what ways do they 
reflect or disrupt dominant modes of recognising difference under liberal multiculturalism?

To explore these questions, I outline how 'multicultural library services' have been defined and inscribed in Australia. To do this, I focus on how previous generations of librarians in Australia have altered collections and practices in the context of rapid social and political change. Specifically, I analyse responses from the library sector to the policy context of 'early' state multiculturalism. I focus on the activities of the Working Group on Multicultural Library Services (Victoria), an independent group of librarians that was the first of its kind in the Australian library sector to develop a strategic response to social and cultural pluralism ${ }^{2}$. I chose to focus on this group because of its involvement in several key events following the implementation of multicultural policy and its influence in this 'area' of library practice, including internationally (Holmes et al., 1987).

\section{Methods and data: Tracing 'multicultural library services' in Australia}

My findings are based on archival research and semi-structured interviews with three key Group members. As one former member noted in our interview, the Group rigorously documented its activities, both for posterity and to assist in the operationalisation of 'multicultural library services' in workplaces. As such, there is a relatively large amount of published and unpublished material on the group. With strong connections to the State Library Victoria (SLV), many of the newsletters, journals and reports authored and published by the Group and its members are held in the SLV

\footnotetext{
${ }^{2}$ The Group was not directly associated with the Library Association of Australia (LAA), the previous incarnation of ALIA, although there was collaboration between the two groups.
} 
collection. A particularly valuable source was the Group's quarterly newsletter (and later journal), Multicultural Libraries (1980-2002). Relevant conference and workshop proceedings from 1975 ('Library Service to Migrants'), 1980 ('Multiculturalism and Libraries'), and 1985 ('Directions for Diversity') were also useful in framing key developments. The 1980 and 1985 conferences, each facilitated by the Group, were particularly valuable, providing a vivid account of the debates that circulated in the sector at the time. Standards, research reports, annotated bibliographies, and directories either authored by Group members or published or co-published by the Group were also referred to.

My interviews with Group members lasted between one and two hours and were conducted in libraries across Victoria. These three Group members were active and interested in library services to migrants prior to its establishment in 1979, and two were founding members. Many had seen demographic changes in their local communities throughout the 1970s that demanded the development of new collections and programs. All were involved in the Group at its most active (throughout the 1980s) and some stayed involved until the 1990s. I also integrate primary and secondary sources relating to the broader political and policy context of Australian multiculturalism. These policies are widely available, and there is a strong body of work from political science, sociology, and history on both the politics of multiculturalism and experiences of lived diversity. A combination of these sources is used in interplay with archival research and interviews to formulate my findings. I acknowledge several limitations of my approach. First, speaking to only three Group members provides a partial view of this history. Given its thirty-year history, I mainly focus on two key developments: the state-wide adoption of the Group's Standards for multicultural public library service (1982) and lobbying by the Group for a national languages policy and federal government funding 
for public libraries (1987). Second, I acknowledge my approach is largely 'top-down' and implicitly sidelines the role of migrant groups and others 'on the ground' in lobbying and advocating for change. As such, this paper provides a single reflection on a set of complex historical processes.

\section{Multiculturalism and libraries in Australia: defining and inscribing a sector- wide approach}

\section{The steady emergence of cultural and linguistic diversity as a topic of concern in the Australian library sector (1970-1978)}

Prior to the first National Multiculturalism and Libraries conference in 1980, a changing social and political landscape saw 'cultural difference' emerge as a topic of concern in the Australian library sector. The 1960s and 1970s saw successive waves of migration from increasingly diverse origins, demands from politically active migrant groups for equality, and the emergence of multicultural policies and programs. From 1970, discussions around 'books in foreign languages' and 'library services to migrants' became topics of discussion in the sector (LAA, 1970). For example, the Library Council of Victoria's (LCV) 1970 strategic plan recognised the need to service 'newcomers with limited knowledge of the language and/or customs of the area'. While assimilationist language frames these early efforts, with the steady emergence of multiculturalism as an official policy position in the early 1970s, there was a recognition that libraries were expected to alter collections and services to reflect the results of Australia's demographic and political transformation.

In 1972, a working party was formed in Victoria to advise the State Librarian 'whether the LCV should contribute to library services in Victoria... in languages other than English and to persons whose native language is not English' through a survey of the linguistic makeup of collections in the state's school and public libraries. It is clear 
that 'multicultural library services' had yet to take shape at this point. Despite growing political demands from community groups and migrant activists, public institutions were yet to respond meaningfully to demands for equal access and equal opportunity. Perhaps unsurprisingly, the working party found that public libraries were significantly lacking in community language materials, resulting in one-off funding for materials in eight languages (State Librarian's Working Party on Foreign Language Collections (Victoria), 1987). The institutionalisation of 'multicultural library services' had commenced. New forms of professional expertise emerged, typified by the newly established role of 'Ethnic Services Librarian' at SLV. This role was established in 1974 to 'act as a liaison between libraries, ethnic communities and publishers of material' and similar roles would soon emerge in other institutions (Sukkel, 1990). In these early examples, a changing social and political landscape saw the linguistic diversity of holdings emerge as an issue of concern and slowly become institutionalised, with people, resources, and expertise coalescing around a fledgling 'multicultural library services'.

On the back of these early developments, the LCV organised a workshop on 'Library Service to Migrants' as part of the 1975 LAA Conference (Whitehead \& LCV, 1976). The workshop, featuring representation from emergent ethnic community organisations, highlighted early experimentation in altering the make-up of collections and selected services. A lack of representation in public library collections and services was now seen a social justice issue, with a workshop participant, Alan Matheson from the Ecumenical Migration Centre, summarising the status quo as:

[Libraries have] institutionalised your discrimination [by] not recognizing the rights of the minorities within your community. You've not provided any services. You've been most uncreative... How do you begin to break those sorts of nexuses 
that institutionalise what ethnic groups feel is very real discrimination and a denial of their rights[?] (Whitehead \& LCV, 1976)

The workshop's key recommendation - a coordinated approach from the library sector to multiculturalism - sought to initiate widespread changes to Victorian public library services. Such a strategic direction laid the foundation for the establishment of the Victorian Working Group in 1979, along with several interstate groups in years immediately following (Bell, 1993; Working Group on Multicultural Library Services (N.S.W.), 1983). ‘Multicultural library services' had begun to solidify.

In this 1970-1978 period, the framework in which public libraries conceived of 'cultural difference' reflected the emerging politics of multiculturalism. There has been a lot of criticism of the dominant way of demarcating groups under state multiculturalism. Particularly, it has been critiqued for essentialising culture and identity according to homogeneous and static 'ethnic' communities. Such an approach is outlined by Ghassan Hage (1998) in his influential book White Nation, where he argues that both proponents and opponents of multiculturalism pursue discourses and practices that construct minorities as problematic objects in need of management by white subjects. In contemporary Australia, where the 'rational' market tends to reflect the differential power of social actors, multiculturalism is understood to maintain the hegemony of the dominant culture, while appearing a neutral, unproblematic 'social good'. These understandings complicate conservative narratives of multiculturalism that inflate the role public policy plays in shaping society, particularly the social lives of minorities. As we shall see, an emergent 'multicultural library services' reflected this mould, advancing the notion of clearly demarcated groups with discrete needs that could be measured and catered for within a normative cultural framework. 


\section{The formation of the Working Group on Multicultural Library Services}

(Victoria) and the 'heyday' of multiculturalism (1978-1982)

In the policy environment of the late 1970s, members of the would-be Working Group recognised a specific role for libraries in a multicultural society. Under the leadership of Radha Rasmussen, who researched and taught on 'library services to migrants' at Monash University, the Working Group first met in August 1979 to define their objectives. The Group provided a venue for like-minded librarians to independently develop a sectoral response to multiculturalism in Australia, with the aim of modifying mainstream services and collections according to the needs of distinctive groups. The emergence of 'multicultural library services' needs to be understood in the context of formative state policies of multiculturalism in the late 1970s, that defined a role for educational and cultural institutions in promoting and endorsing a multicultural society.

On a political level, the key development in multicultural policy in the lead-up to the 1980s was Barrister Frank Galbally's 1978 review of government-funded programs and services for new migrants, seen as the 'foundation document of multiculturalism' in Australia (Jupp, 2002, p. 87). The conservative government's adoption of its recommendations saw an expansion in services relating to housing, language development, and education for migrants. The 'Galbally Report', as it is widely known, cemented the link between multiculturalism and ethno-specific welfare provision, expanding and re-designing services to support migrant settlement and cultural maintenance in the context of a conservative, austerity-driven government (Jakubowicz, 1981; 1994). The Galbally Report put into operation multiculturalism's reliance on neatly delimited ethnic categories as its main building block; a model of managing pluralism that Ang (2001, p. 199) describes as 'living apart together'. 
In this social and political context, there was acknowledgement among Group members that non-English language library collections were scarce, of poor quality, and rarely used or updated. Members of the Group I interviewed highlighted their aims to develop policy in the sector that routinely incorporated an understanding of 'cultural difference' (in the 'ethnic group' model characterised in the Galbally Report), with the objective of establishing consensus and influencing funding models. There was acknowledgement that libraries needed to move beyond tokenistic gestures of inclusion. Published shortly after, the first newsletter of the Group defined their official objectives, and lay the foundations for its activities over the next decade:

(1) To provide an information exchange on matters relating to multicultural librarianship.

(2) To promote the use of libraries by all cultural groups in the community.

(3) To provide a focus for co-ordinated activity in improving multicultural library services.

(4) To provide professional leadership in this aspect of librarianship.

(5) To seek the views of potential library users from amongst aboriginal [sic] and non-English speaking migrant groups.

(6) To seek contact, discussion, and participation with other groups and individuals concerned with multicultural issues.

(7) To promote the greater availability of books and other materials in languages other than English by supporting local publishing and distribution.

Recognising that many of their institutions were developed in a context where the fiction of a white Australia persisted, the Working Group set about strengthening and standardising what a 'multicultural library service' might look like. Standardising library collections and services to cater for Australia's emerging mode of understanding cultural difference was the first and most urgent recommendation from the national conference in 1980. As such, an immediate task upon the Group's foundation was to develop the Standards for multicultural public library service (Working Group on 
Multicultural Library Services (Victoria) Standards Subcommittee, 1982). Published by the LCV in 1982 and adopted as a standard for public libraries across several states, the standards were later used to form the basis of the International Federation of Library Associations' Guidelines on Library Services to Multicultural Communities, published in 1987 with involvement from key members of the Working Group (Holmes et al., 1987). In this way, Australia's model of multiculturalism, at first defining a local response, arguably framed discussions of public library services to culturally diverse populations internationally.

The Standards for multicultural public library service drew on the framework extant in multicultural policy at the time to outline how mainstream library services were to be modified to align with aims of official multiculturalism. The key focus was on what public libraries could do to provide access to resources in languages other than English. The standards recommended furnishing current library collections with 'multicultural' publications and services according to the number of non-English speakers in local government areas. Recognising the primacy of the English language in the publishing industry, and the disparate landscape of 'foreign language' publishers and distributors, the Group supported libraries to surmount these challenges. A Group member I spoke to recalled their library's practice of engaging the services of booksellers who would travel abroad to buy books on its behalf, annotating them prior to delivery to support cataloguing. To support other libraries, the Group produced guides and facilitated workshops on buying books in other languages (Holmes \& Whitehead, 1983) and published research on the reading habits of different migrant groups (Ashby \& Whitehead., 1988). Cooperative lending and cataloguing arrangements were also established to support maximum use of scarce non-English 
language resources, a model which persists in the contemporary context (Acevedo \& Bresnahan, 2005).

By setting quotas for the provision of materials in a range of languages according to population-level data, the Standards for multicultural public library service followed the rubric of official multiculturalism, where 'cultural difference' was mobilised, categorised, and accommodated through prescriptive categorisation. 'Multicultural library services' involved quantitative measurement of discrete groups using census data to set the benchmarks on the 'ideal' make-up of collections. In the excerpt from the standards below, we see the principles that govern 'multicultural library services' and model of allocated resources based on culturally stratified population numbers:

[mc-lib-services-JALIA-11Jan2021-figure1.jpg]

Figure 1: Working Group on Multicultural Library Services (Victoria) Standards Subcommittee. (1982). Standards for multicultural public library service [excerpt]. Library Council of Victoria.

I view these standards as an experiment, defined by the technological and political context of the time, to standardise the inclusion of different language content in public library collections. By the time of the second national conference on multiculturalism and libraries in the mid-1980s, Group members noted that these ways of responding to linguistic pluralism in libraries were becoming increasingly mainstream across the country. The Standards for multicultural public library service surely played an important role. 


\section{Positioning libraries as a central pillar in a multicultural society amidst a globalising economy (1982-1989)}

The Group not only responded to broader political developments, but actively sought to position libraries as occupying an important position in the promotion and endorsement of multiculturalism. This was achieved through written submissions and appearing in several national inquiries seen to relate to multicultural library services. Of note was the Group's involvement in lobbying for a systematic national approach to language rights and multilingualism (Whitehead, 1992). After several years of lobbying from groups including the Working Group on Multicultural Library Services (Victoria), the federal government adopted Australia's National Policy on Languages, the Englishspeaking world's first national plan to foster multilingualism. The policy promoted the learning of languages that were of economic and strategic significance, as well as supporting linguistic maintenance as both a fundamental right and of value in an increasingly globalised economy. With support from members of the Working Group and advocacy for libraries from its author Joseph Lo Bianco, the plan embedded the role of public libraries in supporting multilingualism, recommending libraries increase stocks of non-English language materials and support access to information on 'Asian languages, business, culture and trade' (Lo Bianco, 1987, p. 180). This focus reflects the increasing strategic and economic importance of the region in the context of a rapidly changing global economy. In this context, members of the Working Group and Lo Bianco also lobbied (unsuccessfully) for federal funding of public libraries, based on the tripartite connection made in the National Policy on Languages between federal immigration policy, education policy and library services. Such initiatives reflected a perceived role for libraries in building the linguistic and cultural skills of the population in order to participate in a rapidly globalising economy. This is the start of the discourse of 'cultural competence', where the building a 'cultural competent' workforce became a 
method of ensuring Australian businesses could participate (and compete) in a contemporary global market. In such a framework, Australia's ongoing racial politics becomes a risk to be managed, rather than a site for acknowledgement and reparation.

The 1980s were a decade of massive economic upheaval in Australian society, along with a growing number of voices demanding participation in the public sphere. In 1989, the Hawke Government released its key statement on multiculturalism, the National Agenda for a Multicultural Australia, that largely set the policy agenda for the next decade. This statement identified 'the right of all Australians, within carefully defined limits [emphasis added], to express and share their individual cultural heritage, including their language and religion' (Office of Multicultural Affairs, 1989). Libraries, museums, and galleries specifically had a role to represent the full diversity of all Australians (Consultative Committee on Cultural Heritage in a Multicultural Australia, 1991). However, without disrupting dominant modes of expression in the sector, this celebratory and inclusionary approach was incapable of challenging the entrenched stratification of Australian society. Quite the opposite; the simultaneous liberalisation of the economy and a growing emphasis on 'productivity' in the public sector individualised inequalities that were deeply social and structural. The National Agenda for a Multicultural Australia saw the beginning of an emphasis in multicultural policy on deploying the strategic and economic benefits of cultural diversity. This was a crucial juncture in the shift in multiculturalism from a social and cultural policy tailored to migrants to an economic strategy used to promote 'diversity' for political and economic ends (Walsh, 2014).

Since the late 1980s, cultural diversity has been mobilised in national discourse to serve political and economic ends. Under this 'productive diversity' framework, cultural pluralism is promoted as a mode of capitalist consumption and 'difference', 
within carefully defined limits, becomes desirable as a form of commodity. As part of a commodification of culture, 'cultural differences are paraded as apolitical ethnic accessories celebrated in multicultural festivals of costumes, cooking, and concerts' (Gunew, 1997, p. 24). This process is seen to have a productive role in serving the liberal regulatory ideal of decreased harm through mutual understanding of social and cultural difference. In this context, difference is welcomed and made visible as a market-driven commodity, limiting more complex forms of representation in mainstream culture. In the mid to late 1980s, libraries emerged as public sites for the provision of information resources to support individual economic mobility. In a 'multicultural library service', supporting cultural and linguistic maintenance and development was no longer just a human right, it became an economic and political imperative. Principles of economic rationalism became central to public service delivery, and libraries became immersed in the upheaval wrought by a neoliberal Australia.

\section{Structural and political challenges to 'multicultural library services' (1990-} 2002)

The 1990s was a time when libraries were experiencing draining collections budgets, impacting the ability to provide services seen as peripheral to 'core business'. The Victorian state government under Premier Jeff Kennett undertook a campaign of economic rationalisation that impacted public libraries through local council amalgamation and compulsory competitive tendering. Group members I spoke to noted the drastic impact of economic rationalism in areas of public service provision on the library services they managed. Increasing the linguistic diversity of collections, often sporadic and project-based, became less of a priority. Looking at the journals of the Working Group from the period, there was increasing discussion on initiatives and 
projects to build economic capability needed to sustain linguistically diverse collections and services, rather than offering a forum for collectively resisting a market-driven logic. In this context, energy visibly faded from the Group, following the departure of several key committee members.

Just as the early 2000s saw a retreat from multiculturalism in public policy, the focus diminished in the library sector. While notions of social cohesion and national allegiance were embedded in multicultural policy since at least the Labor government's National Agenda for a Multicultural Australia, this intensified following the election in 1996 of conservative prime minister John Howard, never a fan of multiculturalism. The language of social justice and rights largely disappeared from multicultural policy, replaced by a discourse of obligation and unity (Department of Immigration and Multicultural Affairs, 1999). In this context, the Working Group had become increasingly 'moribund', as one former member put it, still meeting quarterly, but less influential in shaping and responding to policy. The Group as it was known ceased its activities in 2002 and was subsumed into the Public Libraries Network as an informal special interest group. In the same year, ALIA withdrew its policy on multiculturalism and libraries, which had been adopted in 1984 and revised and re-endorsed several times since (ALIA, 2002) ${ }^{3}$.

\section{Conclusion: Reflecting on the history of 'multicultural library services' in the} Australian library sector

Multicultural policies and programs in Australia emerged in the early 1970s, as the government sought to mobilise a heterogenous yet cohesive national identity and

\footnotetext{
${ }^{3}$ I requested information from ALIA regarding the reasons for the withdrawal of the policy, however, I did not receive a response.
} 
manage the limits of cultural expression among a diverse population. Despite the mainstream celebration of multiculturalism as an inclusive politics of recognition, state multicultural policy has done little to disrupt the centrality of white Australians in managing such a politics. The rhetoric of 'celebrating Australia's diversity' was amplified in the 1980s and early 1990s, when Australia's demography was strategically positioned outward to emerging trading partners in Asia, before becoming more contested in the Howard era.

The Working Group on Multicultural Library Services (Victoria) were influential in defining a sectoral response to such a politics from the 1970s to the 1990s. 'Multicultural library services' had a particularly strong focus on non-English speaking migrants, with an assumption that identities and cultures are discrete, measurable entities that could be catered for under a normative framework, as seen in official multicultural policy. The politics of an emergent state multiculturalism and demands from migrant groups allowed a lack of representation in collections and services to be seen as a denial of rights. To this end, the Group advanced the recognition of cultural and linguistic difference in collections through population-level data to set benchmarks on the composition of 'ideal' collections and services. Influential publications, projects and conferences allowed such 'multicultural library services' to be standardised across the sector. While this undoubtedly diversified collections and services to support a multicultural community of users, such an approach uses prescriptive categorisation to depict heterogenous groups as bounded and static. The recognition of difference under this logic of liberal multiculturalism produces a certain subject position; one framed in terms of deficits or divergences from the norm and limited in its political potential. The fact that inequalities in political and material power have been sustained throughout the 
ebb and flow of state multiculturalism reflects the limits of a liberal multicultural framework as it increasingly becomes subjected to the logic of the market.

Contemporary initiatives in the sector that 'celebrate' diversity or train staff in 'cultural competence' are deeply limited solutions to the inequalities seen under increasingly conservative permutations of multiculturalism. These approaches are a legacy of constructing difference as something to be neutralised or fashioned into a commodity, rather than providing alternative ways of envisaging the form and function of libraries in contemporary Australian society. Meanwhile, independent, experimental, and activist libraries are being established, providing alternative models for enabling forms of knowledge production that resist the commodification and colonisation of culture (Emerging Writers Festival, 2019). With the emergence of the critical librarianship movement in Australia, new ways of resisting conservative and neoliberal arrangements of multiculturalism may offer an alternative path for Australian libraries, but only with the sustained and collective effort of which the Working Group on Multicultural Library Services (Victoria) has provided such a strong example. 


\section{Reference list}

Acevedo, O., \& Bresnahan, K. (2005). Providing and promoting public library services to a culturally diverse New South Wales. Australasian Public Libraries and Information Services, 18(2), 59-70.

Ahmed, S. (2000). Strange encounters: embodied others in post-coloniality. Routledge. Ang, I. (2001). On not speaking Chinese: living between Asia and the West. Routledge. Ashby, J. \& Whitehead, D. (1988). Not enough to read: the report of a survey of the reading interests of six migrant communities in Melbourne. Working Group on Multicultural Library Services (Victoria).

Australian Library and Information Association. (2002, August 11). ALIA's policies. http://web.archive.org/web/20020811180418/http://www.alia.org.au:80/p olicies/

Australian Library and Information Association. (2019). Workforce diversity trend report 2019. https://read.alia.org.au/workforce-diversity-trend-report2019

Bell, M. (1993). South Australian Working Group on Multicultural Library Services: its history and development 1979-1993. South Australian Working Group on Multicultural Library Services.

Blackburn, F. (2015). 'Cultural Competence is for Everyone': Cultural Competence in the United States Library and Information Sector. Is It Relevant to Australian Libraries? Australian Academic \& Research Libraries, 46(3), 176-193. https://doi.org/10.1080/00048623.2015.1063800

Castles, S. (1992). The challenge of multiculturalism: global changes and Australian experiences (Report No. 19). Centre for Multicultural Studies, University of Wollongong. http://ro.uow.edu.au/cmsworkpapers/17 
Consultative Committee on Cultural Heritage in a Multicultural Australia. (1991). A plan for cultural heritage institutions to reflect Australia's cultural diversity. Australian Government Publishing Service.

Department of Immigration and Multicultural Affairs. (1999). A new agenda for multicultural Australia.

Diversity Arts Australia. (2019). Shifting the balance: cultural diversity in leadership within the Australian arts, screen and creative sectors. http://diversityarts.org.au/app/uploads/Shifting-the-Balance-DARTSsmall.pdf

Emerging Writers Festival. (2019, October 30). Remaking Libraries. https://2019.digitalwritersfestival.com/event/remaking-libraries/

Galbally, F. (1978). Migrant services and programs: report of the Review of Postarrival Programs and Services for Migrants, May 1978. Australian Government Publishing Service. https://nla.gov.au/nla.obj-1474121432

Gunew, S. (1990). Multiculturalism Is for Everyone: 'Australians' and 'Ethnic' Others. In B. Hocking (Ed.), Australia Towards 2000 (pp. 100-113). Palgrave Macmillan. https://doi.org/10.1007/978-1-349-10785-8_9

Gunew, S. (1997). Postcolonialism and Multiculturalism: Between Race and Ethnicity. The Yearbook of English Studies, 27, 22-39.

https://doi.org/10.2307/3509130

Gunew, S. (2004) Haunted nations: the colonial dimensions of multiculturalisms. Routledge.

Hage, G. (1998). White nation: Fantasies of white supremacy in a multicultural society. Pluto Press. 
Holmes, A., \& Whitehead, D. (1983). Buying books in other languages: a handbook for Australian school and public libraries. National Library of Australia.

Holmes, A., Whitehead, D., \& International Federation of Library Associations. (1987). Multicultural communities: guidelines for library service.

Holmes, A., Whitehead, D., \& Rasmussen, R. (1981). Multiculturalism and libraries: proceedings of the National Conference on Multiculturalism and Libraries held at Normanby House, Monash University, 7-11 November 1980. Working Group on Multicultural Library Services (Victoria).

Holmes, A., Whitehead, D., \& Working Group on Multicultural Library Services (Victoria). (1986). Directions for diversity: proceedings of the second National Conference on Multiculturalism and Libraries held at St Mary's College, University of Melbourne, 15th-19th February 1985. Working Group of Multicultural Library Services (Victoria).

Hudson, D. J. (2017). On "diversity" as anti-racism in library and information studies: a critique. Journal of Critical Library and Information Studies, 1(1), 1-26. https://doi.org/10.24242/jclis.v1i1.6

Jakubowicz, A. (1981). State and ethnicity: multiculturalism as ideology. The Australian and New Zealand Journal of Sociology, 17(3), 4-13. $10.1177 / 144078338101700302$

Jakubowicz, A. (1994). Ethnic leadership, ethno-nationalist politics and the making of multicultural Australia. People and Place, 2(3), 20-28.

Jupp, J. (2002). From white Australia to Woomera: the story of Australian immigration. Cambridge University Press. 
Library Association of Australia (Ed.). (1970). Undervalued areas in public

librarianship. Victorian Division, Public Library Section, Library Association of Australia.

State Librarian's Working Party on Foreign Language Collections (Victoria). (1987).

Foreign language service in Victorian libraries: a report to the state librarian, K.A.R. Horn, April 1974. Working Group on Multicultural Library Services (Victoria).

Library Council of Victoria (Ed.). (1985). Directory of materials in languages other than English held by public libraries and ethnic community organisations in Victoria (3rd ed.).

Lo Bianco, J. (1987). National policy on languages. Australian Government Publishing Service. http://hdl.handle.net/11343/112286

Maestro, R. S., Ramos-Eclevia, M., Jr, C. L. E., \& Fredeluces, J. C. L. T. (2018). Teaching Diversity, Becoming Inclusive: Perspectives and Possibilities in ASEAN Library and Information Science Schools. Journal of the Australian Library and Information Association, 67(2), 96-115. https://doi.org/10.1080/24750158.2018.1467142

McCulloch, A. (2020). Recognising critical librarianship. INCITE (January-February), 24.

Office of Multicultural Affairs. (1989). National agenda for a multicultural Australia: sharing our future (Catalogue number 8907669). Australian Government Publishing Service.

Pawley, C. (2006). Unequal Legacies: Race and Multiculturalism in the LIS Curriculum. The Library Quarterly, 76(2), 149-168. https://doi.org/10.1086/506955 
Povinelli, E. A. (1998). The state of shame: Australian multiculturalism and the crisis of indigenous citizenship. Critical Inquiry, 24(2), 575-610. https://doi.org/10.1086/448886

Povinelli, E. A. (2002). The cunning of recognition: Indigenous alterities and the making of Australian multiculturalism. Duke University Press.

Stratton, J. (1998). Race Daze: Australia in Identity Crisis. Pluto Press.

Stratton, J., \& Ang, I. (1994). Multicultural imagined communities: Cultural difference and national identity in Australia and the USA. Continuum, 8(2), 124158. https://doi.org/10.1080/10304319409365672

Sukkel, L. (1990). Staffing of multicultural library positions in Victoria. Department of Employment, Education and Training Victoria.

Thorpe, K. (2019, January 23). Transformative praxis - building spaces for Indigenous self-determination in libraries and archives. In the Library with the Lead Pipe. http://www.inthelibrarywiththeleadpipe.org/2019/transformativepraxis/

Walsh, J. P. (2014). The marketization of multiculturalism: Neoliberal restructuring and cultural difference in Australia. Ethnic and Racial Studies, 37(2), 280301. https://doi.org/10.1080/01419870.2012.720693

Whitehead, D. (1992). Libraries and a national language policy: a discussion paper. Melbourne: Working Group on Multicultural Library Services (Victoria).

Whitehead, D., \& Library Council of Victoria. (1976). Library Service to Migrants: proceedings of a workshop held at the State Library of Victoria on 28th and 29th August, 1975, as part of the 18th Biennial Conference of the Library Association of Australia. Library Council of Victoria. 
Working Group on Multicultural Library Services (N.S.W.). (1983-2002). Break through: newsletter of the Working Group on Multicultural Library Services (N.S.W.).

Working Group on Multicultural Library Services (Victoria). (1980-1983).

Multicultural libraries newsletter: newsletter of the Working Group on Multicultural Library Services.

Working Group on Multicultural Library Services (Victoria). (1983-2002).

Multicultural libraries: journal of the Working Group on Multicultural Library Services (Victoria).

Working Group on Multicultural Library Services (Victoria) Standards Subcommittee. (1982). Standards for multicultural public library service. Library Council of Victoria. 
Library materials in their preferred language should be provided for all.

10

Within a particular state, an effective, balanced and substantial collection should be maintained for each linguistic minority.

11 The provision of library materials for members of linguistic minorities should be related to the numbers

[...] of persons who use the language of that group.

\section{Books}

12

The standard for book provision on a total state basis is:

\begin{tabular}{c}
$\frac{\text { Population of }}{\text { language group }}$ \\
\hline 300,000 \\
200,000 \\
100,000 \\
70,000 \\
35,000 \\
20,000 \\
10,000 \\
5,000 \\
2,500 \\
1,500
\end{tabular}

\begin{tabular}{rll} 
Bookstock & (per capita) \\
\hline 300,000 & $(1)$ \\
250,000 & $(1.25)$ \\
150,000 & $(1.5)$ \\
100,000 & $(1.43)$ \\
70,000 & $(2)$ \\
45,000 & $(2.25)$ \\
25,000 & $(2.5)$ \\
13,750 & $(2.75)$ \\
7,500 & $(3)$ \\
5,000 & $(3.5)$
\end{tabular}

Acquisition per annum 37,500 31,250 18,750 12,500 8,750 6,625 3,125

1,720 940 625 